\title{
In Search of Het Behouden Huys: A Survey of the Remains of the House of Willem Barentsz on Novaya Zemlya
}

\author{
LOUWRENS HACQUEBORD ${ }^{1}$
}

(Received 19 September 1994; accepted in revised form 24 March 1995)

\begin{abstract}
In August 1992, a Russian-Dutch expedition organized by the Arctic and Antarctic Research Institute in St. Petersburg, Russia and the Arctic Centre of the University of Groningen, The Netherlands surveyed the site of the house on Novaya Zemlya in which the Dutch explorer Willem Barentsz and his crew spent the winter of 1596-97. This survey made it clear that the plundering of the site had been so profound that an excavation would be useless. Comparison of the results of the 1992 survey with the observations made by Elling Carlsen, who discovered the site in 1871, showed that it is improbable that all the remaining objects are still in situ. However, the field study and the supplementary historical research nevertheless cast some new light onto interesting aspects of this notable event in the history of the discovery of the region around the North Pole. The visit to the site made clear that the house was built on a peninsula, and not on the shore of a bay as had been thought up to now. The immediate surroundings turned out to be flat, and not hilly as historical illustrations suggested. It was also evident that these illustrations usually show a mirror image of the house. The house appears to have been constructed in the log cabin manner, with beams which slotted into each other at the corners. The objects found in 1992 made it clear that much handiwork was done during the wintering. The bone material informed us about the diet of the winterers, which consisted of salted beef and fox meat.
\end{abstract}

Key words: Arctic, Russia, Barents Sea, Novaya Zemlya, expeditions, Willem Barentsz, wintering, northeastern passage

RÉSUMÉ. En août 1992, une expédition russo-néerlandaise montée par l'institut de recherche arctique et antarctique de SaintPétersbourg en Russie et par le centre arctique de l'université de Groningue aux Pays-Bas a fait une étude du site de la maison construite en Nouvelle-Zemble, dans laquelle l'explorateur néerlandais Willem Barentsz et son équipage passèrent l'hiver de 1596-97. Cette étude a révélé sans nul doute possible que le pillage du site avait été si intensif qu'il était inutile de procéder à des fouilles. Une comparaison des résultats de l'étude de 1992 avec les observations faites par Elling Carlsen, qui découvrit le site en 1871, a révélé qu'il est improbable que tous les objets découverts par Carlsen soient encore in situ. L'étude sur le terrain et la recherche historique supplémentaire ont cependant jeté un peu de lumière sur des aspects intéressants de cet événement notable dans l'histoire de la découverte de la région avoisinant le pôle Nord. La visite sur le site a permis de confirmer que la maison était bien construite sur une presqu'île et non sur le rivage d'une baie comme on l'avait pensé jusqu'à maintenant. Les alentours immédiats se sont révélés plats et non formés de collines comme les dessins historiques le laissaient entendre. Il est également évident que ces illustrations montrent la plupart du temps une image de la maison en miroir. Celle-ci semble avoir été construite dans le style des cabanes en rondins, les madriers s'encastrant les uns dans les autres aux angles. Les objets trouvés en 1992 permettent d'affirmer que l'hivernage donnait lieu à bien des petits travaux de bricolage. Le matériel osseux nous informe sur le régime alimentaire des personnes qui hivernaient là, régime qui consistait en boeuf salé et en viande de renard.

Mots clés: Arctique, Russie, mer de Barents, Nouvelle-Zemble, expéditions, Willem Barentsz, hivernage, passage du Nord-Est

Traduit pour la revue Arctic par Nésida Loyer.

\section{INTRODUCTION}

In the last decade of the sixteenth century, Willem Barentsz and other Dutchmen made three voyages of exploration in search of a northeastern passage to China (Cathay). During the third and last voyage, Barentsz and his crew were forced by the ice to spend the winter on the northeastern tip of Novaya Zemlya (Fig. 1). They built a house there and the majority of the crew managed to survive the polar winter of 1596-97. Never before had any European wintered so far north (Hacquebord, 1991).
The winter spent by Barentsz and his crew on Novaya Zemlya in 1596-97 has always appealed to the imagination of the Dutch. This is due in part to the impressive diary of Gerrit de Veer, later translated into several languages, and the well-preserved artifacts found on Novaya Zemlya in 1871. These artifacts now form an important part of the collections of the Rijksmuseum in Amsterdam.

An unexpected opportunity to send a Russian-Dutch expedition to Novaya Zemlya to survey the site where Willem Barentsz and his crew spent the winter arose in August 1992. It was the first time since 1876 that westerners had been able to examine the remains of this famous place.

${ }^{1}$ Arctic Centre, University of Groningen, Oude Kijk in 't Jatstraat 26, Postbus 716, 9700 AS Groningen, The Netherlands

(C) The Arctic Institute of North America 


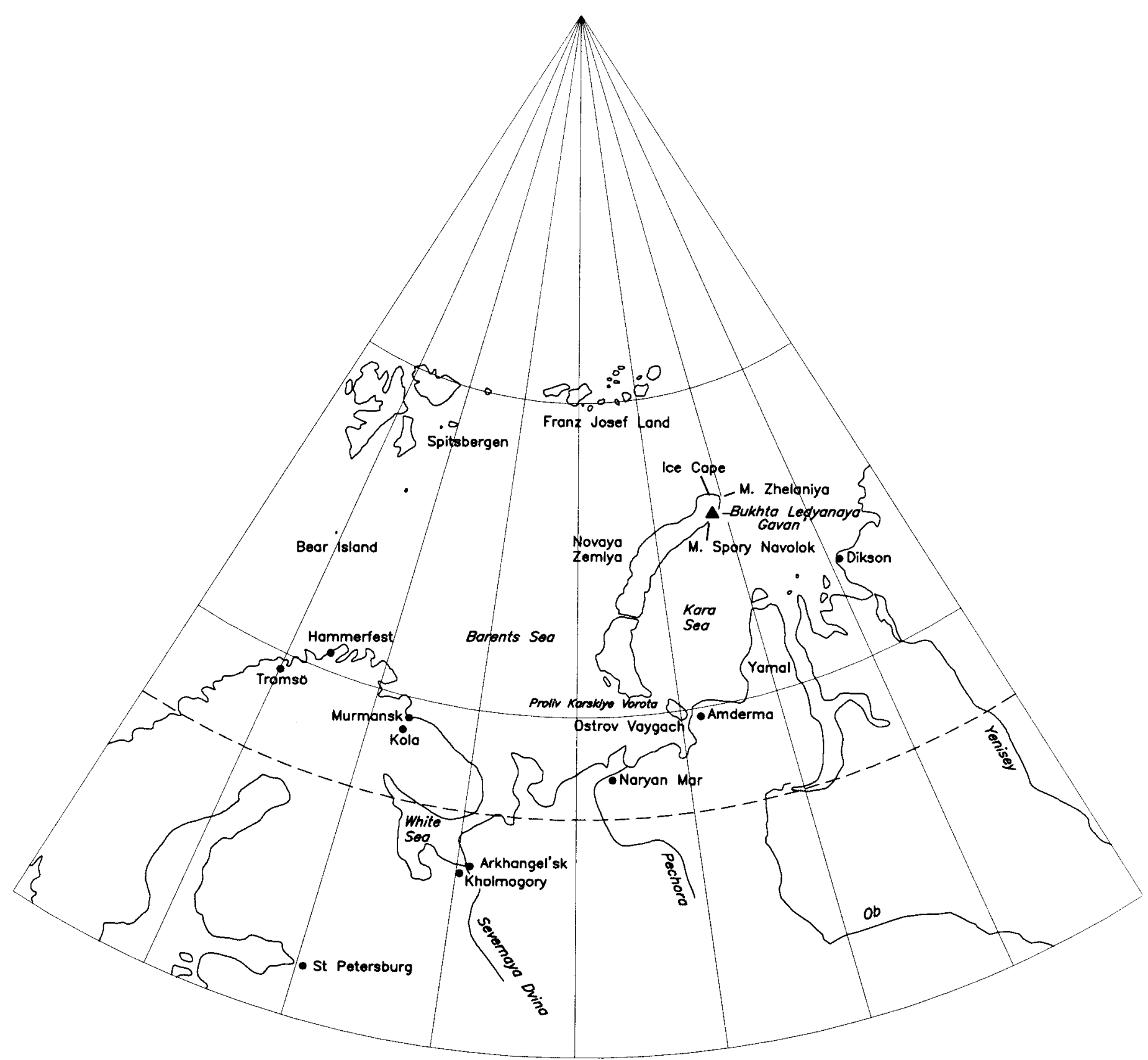

FIG. 1. Map of the Barents Sea region (drawing by H.J. Waterbolk; photo by CFD-RUG). $\boldsymbol{\Delta}$ location of the house of Willem Barentsz on Novaya Zemlya.

\section{THE WAY TO CATHAY}

Halfway through the sixteenth century, Dutch trade began to expand beyond western Europe. In this period the Dutch wanted a sea passage to Asia, and preferably one beyond the reach of the Portuguese and the Spanish. Following the example of the English and the French, they too searched for such a sea passage in the north (Armstrong, 1984; Baron, 1985).

Around 1560 some Dutch merchants founded a trading post on the Kola Peninsula. From Kola they sailed to the White Sea and anchored there in the delta of the River Dvina in 1578. One of the key figures in this trade was Olivier Brunel, who came from Flanders. Brunel's interests went beyond trade with the North, however. He was looking for a northern passage to China. He had spent some time in northern Russia, and, with the help of the Nentsy, had probably already reached the River Ob. In 1584, at the behest of Balthasar de Moucheron, a merchant from Zeeland, he made a new attempt to find a passage to China. Unfortunately, on his way east he was shipwrecked and drowned in the Pechora Delta in northern Russia (Jansma, 1946; Hacquebord, 1986). Lucas Jansz Waghenaer reproduced Brunel's geographical knowledge of the North in his Thresoor der Zeevaert, a book of charts which also incorporated the most recent English discoveries, published in Leiden in 1592 (Waghenaer, 1592). 


\section{PETRUS PLANCIUS}

Petrus Plancius, a Protestant minister and geographer from Amsterdam, although originally from the Southern Low Countries, knew about the findings of Brunel's voyages and the English voyages of Hugh Willoughby and Richard Chancellor in 1553, Stephen and William Borough in 1556, and Arthur Pet and Charles Jackman in 1580 (Keuning, 1946). There was a lot of contact between geographers on both sides of the English Channel. At first Plancius was heavily influenced by Mercator, and his first map of the world, which appeared in 1590, was therefore a faithful copy of Mercator's small map of the world which had been published in 1587. At that time Plancius was teaching navigation, and through his classes he came into contact with the cartographer and pilot Willem Barentsz. They had many discussions together about possible routes to Cathay.

All sixteenth-century maps assumed that the North Pole was situated on a huge rock in an inland sea fed by the oceans via four powerful rivers. These rivers demarcated four polar islands (Taylor, 1956; Wallis, 1984). Novaya Zemlya was thought to be one of the polar islands, and the Barents Sea a dividing river. Plancius, too, drew the polar islands on his maps of the world between 1592 and 1594. On the 1592 map he drew Novaya Zemlya as an independent island for the first time, separated from the polar island in question. On his 1594 map, however, Novaya Zemlya - at least on the main mapis once again attached to the polar island. The accompanying smaller map shows Novaya Zemlya as a double island, and also shows the islands which Willoughby thought he saw on his voyage of discovery in 1553 . One of the polar islands is depicted as smaller than before on a subsequent map of the two hemispheres published by Plancius in Jan Huygen van Linschoten's Itinerario of 1594 (Kern, 1910). Novaya Zemlya is also shown as two islands on this map, and Willoughby Land and Macsinof Island are shown to the west of them. These latter two were probably added to the map to satisfy the English conception of the area. In a written explanation on the map, Plancius made it clear that he did not believe in the polar islands, but depicted them in order to forestall the view that he had forgotten something. This map shows that Plancius supposed there to be a small passage near Ostrov Vaygach and a wide strait to the north of Novaya Zemlya, and that he believed in an open polar sea; not a polar sea without ice, but a sea without land. According to Plancius, Pet and Jackman's voyage in 1580 had clearly shown that the passage to China should not be sought along the Siberian coastline, but much farther north (l'Honoré Naber, 1917).

Barentsz was certainly aware of all these developments. He had not only followed Plancius's courses, but was also well-read in the cartographical literature of the period. The fact that he had himself published a Caertboeck [Book of Charts] for the Mediterranean Sea in 1594 shows that he had a thorough knowledge of charts. In addition, Waghenaer's Den Nieuwen Spieghel der Zeevaert, published in Amsterdam by Cornelis Claesz in 1596, included a map of Ireland and a map of 't Nordelicxste deel van Norweghen' [the northernmost part of Norway] drawn by Barentsz (Waghenaer, 1596).

\section{THE DUTCH IN SEARCH OF THE NORTHEASTERN PASSAGE}

After two unsuccessful voyages of discovery in 1594 and 1595, the merchants from Middelburg and Enkhuizen withdrew from the venture, leaving only those from Amsterdam. In 1596, at the urging of Plancius, the merchants of Amsterdam decided to make a third attempt and to send two ships to the north. Jan Cornelisz Rijp was the captain of one ship, and the other was under the command of Jacob van Heemskerck. The direction of the whole expedition was in the hands of Willem Barentsz. The expedition would follow a northern route via the North Pole. At $75^{\circ} \mathrm{N}$ latitude, the two ships discovered an island which was called Bear Island [now Bjørnøya], and at roughly $80^{\circ} \mathrm{N}$ latitude, the ships met the edge of the pack ice. The expedition continued along the edge of the pack ice and discovered the northern coast of a land that they called Het Nieuwe Land of Spitsbergen [The New Land, or Spitsbergen]. Sailing southwards, the expedition explored the west coast of the newly discovered land. Once back at Bear Island, Barentsz and van Heemskerck decided to try the northeastern route once more, while Rijp again chose the northern route.

On 15 August 1596, Barentsz and van Heemskerck arrived at IJskaap [Ice Cape] on Novaya Zemlya. They rounded the cape and continued their journey in a southeasterly direction. The ice in the Kara Sea quickly surrounded them and they became completely trapped by the ice in IJshaven [Ice Harbour]. On 28 August the ship began to burst at the seams, and two days later it was lifted up by the ice. It appeared unlikely that they would get free before the onset of winter. They built a house and became the first Europeans to spend a winter in a place so far north (Fig. 2). Only the next year, on 14 June 1597, did they set out in two sloops to return to civilization. They arrived in Kola in Northern Russia on 2 September. However, they were without Willem Barentsz, who had died on the way back. His body had been buried somewhere on the west coast of Novaya Zemlya (de Veer, 1609).

The survivors returned to Amsterdam wearing their Novaya Zemlya clothes and white fox hats. The northeastern passage had still not been found, ship and cargo were lost, and the leader and four of his companions had not survived the voyage.

\section{THE RESULTS OF WILLEM BARENTSZ'S JOURNEY}

Viewed objectively, however, this voyage should not really be seen as a failure. More previously undiscovered coastline had been discovered on this voyage than on the previous two. Bear Island, the northern and western coasts of Spitsbergen and the northern and eastern coasts of Novaya Zemlya had been discovered, reconnoitred and charted for the first time. Although the stories about the large numbers of 


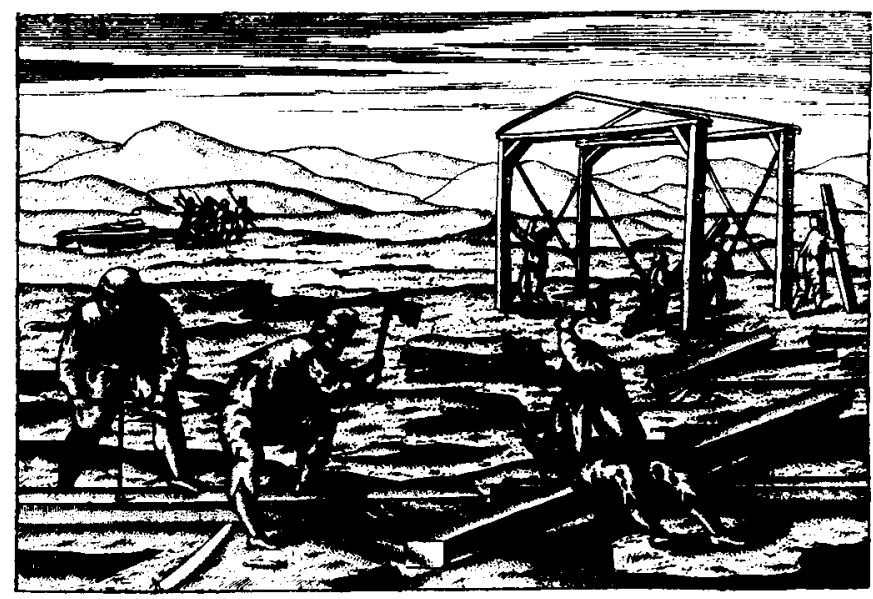

FIG. 2. Engraving of the dragging of the wood and the construction of het Behouden Huys (1'Honoré Naber, 1917).

whales near Spitsbergen did not come from Barentsz but from Hudson and Poole, the geographical information collected by him certainly helped future whalers. In this sense, his discovery and charting of Spitsbergen mean that he can be seen as the founding father of Dutch whaling.

The report of the winterers' experiences, in the shape of the diary of Gerrit de Veer, was published soon after their return. It was complete with many beautiful illustrations, and ran into many editions. By 1598 it had already appeared in Latin, French, and German. In 1599 it was also published in Italian, and in 1609 it appeared in an English edition. It became an internationally renowned book.

The most important result of the voyage, however, was Willem Barentsz's posthumously printed map of the polar region, published by Cornelis Claesz in 1598. This depicted the region as a sea without polar islands, in accordance with Plancius's ideas. Only the Polus Magnetus [magnetic pole], rising like a huge rock out of the polar sea, is still a reminder of Mercator's old concept. A large part of the north and west coasts of Spitsbergen are marked Nieuwe Land [New Land] on this polar chart, the so-called Barentsz chart. Bear Island and Novaya Zemlya are also depicted.

The sponsors of the expedition would probably not have attached much value to these mostly long-term results. The States of Holland were obviously not very impressed with the results of the voyage, because when Barentsz's widow turned to them in 1598 for financial support for her five children, this was denied her (Resolutions of the States of Holland, 17 March 1598). We do not know how she eventually managed to bring up her children, but it cannot have been easy.

\section{PREVIOUS INVESTIGATIONS}

On 9 September 1871, two hundred and seventy-five years after Barentsz and his men landed on the east coast of Novaya Zemlya, the Norwegian seal hunter Elling Carlsen found the remains of a house on the island at a latitude of $76^{\circ} 12^{\prime} \mathrm{N}$. According to Carlsen's journal, the house was 12 yards long and 7.5 yards wide. It was built of driftwood and ship's timbers. The driftwood was used for the crossbeams and for the lowest part of the walls of the house. This part was constructed in the log cabin manner, with four beams set alternately into each other at the corners. A sketch of the remains of the house as Carlsen found it still exists. This sketch, now in the collection of Dr. August Petermann of Gotha, clearly shows the log cabin construction of the house. The crossbeams were placed inside the log wall. The upper part of the walls and the roof were covered with pine shingles $1.5 "$ thick and 14" to 16 " wide. These shingles were attached to each other with nails and hammered onto the crossbeams (l'Honoré Naber, 1917 [2]:81). The sketch only shows the house; the porch had already been dismantled by the winterers, who needed the wood to raise the sides of the boats used for the return journey (Fig. 3).

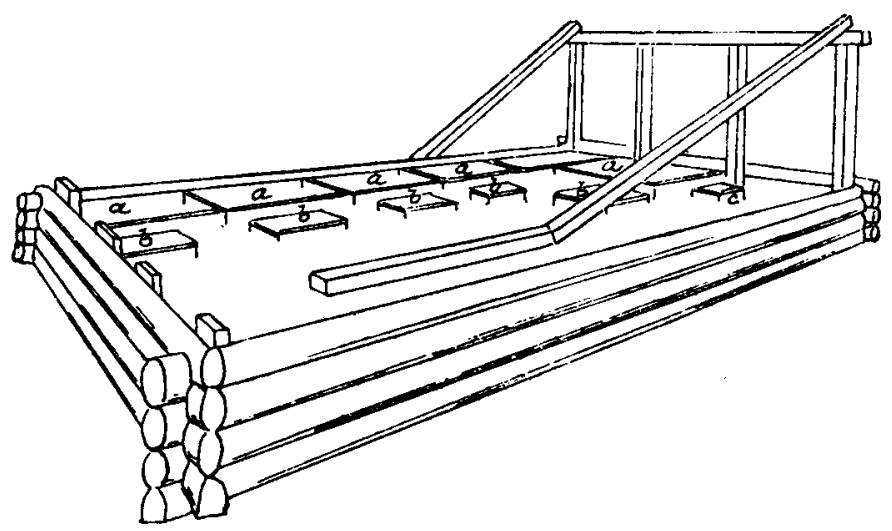

FIG. 3. The sketch of het Behouden Huys as it was found by Elling Carlsen. From the Petermann collection, Gotha (1'Honoré Naber, 1917).

According to his journal, Carlsen found two copper cauldrons, a crowbar, a barrel, a clock, a chest containing various files and other carpenter's tools, a number of pictures, a flute, and several coloured garments. In addition, he found another two empty chests and a cooking tripod or 'fire dog' (de Jonge, 1872).

Three days after their first visit to the site of the house, Carlsen and a few crewmates once more went ashore. The remains of the house were thoroughly searched again, and they discovered more objects. Thus they found candlesticks and tin mugs, a sword, a fragment of a halberd, two books, various parts of nautical instruments, and parts of an iron chest which had mostly rusted away. On 14 September they went to the house for the last time. This time they also dug in the ground, and as a result found drumsticks, the handle of a sword, and some spear or sword points. Carlsen wrote in his journal that the house had afforded shelter to heavily armed people who, as could be seen by the flotsam on the beach nearby, had come from a ship that had been shipwrecked. In addition he ascertained that five berths had been constructed along the wall inside the house. After their inspection of the house, the Norwegians also looked for human remains, but could not find any. Before he returned to Norway, taking the objects with him, Carlsen built a memorial of stones and a 
stake and placed inside it a tin containing a message to possible successors (de Jonge, 1872). The objects were sold in Carlsen's home port of Hammerfest to the English tourist Ellis C. Lister Kay, who then sold them to the Dutch government. Eventually they ended up in the Rijksmuseum in Amsterdam, where they were part of the permanent exhibition in the Dutch History department for a long time. For the last twenty years, they have been in the stores of the museum undergoing examination.

The first person to visit the area after Carlsen was Captain Gundersen on 17 August 1875. He collected a few items, such as a grappling iron, two maps and a handwritten Dutch translation of the account of Pet and Jackman's journey. In 1876 the Englishman Charles L.W. Gardiner visited the place where Willem Barentsz had spent the winter (l'Honoré Naber, 1917). He had been urged to do so by the Dutch polar explorer Koolemans Beynen. He arrived at the spot on 29 July, and collected another 112 objects. The most important object in his collection is the warrant: the message signed by Barentsz and Heemskerck to account for the existence of the house to later visitors (de Jonge, 1877). These objects, too, found their way to the Rijksmuseum in Amsterdam. De Jonge published the first list and description of the objects found on Novaya Zemlya (de Jonge, 1872). The objects found by Gardiner, together with those found by Carlsen, were described by l'Honoré Naber in his two volume work (1917).

As far as we know, the next visitor to the site was Miloradovich of the Arctic Institute in St. Petersburg. In 1933 he ascertained that only very little remained of the house belonging to Barentsz. Together with his assistant, Miss Sychugova, he collected some more objects from the area near the remains of the house, and these eventually ended up in the Arctic and Antarctic Museum (Pineguine, 1933). After Miloradovich, an amateur archaeologist, Dmitriy Kravchenko, visited the site with a team in 1977, 1979 and 1980 and conducted extensive excavations. They seem to have dived in Ice Harbour to examine the remains of Barentsz's ship and searched for Barentsz's grave on the west coast of Novaya Zemlya. Kravchenko made a number of site drawings which show the remains of the building and the location of the objects. In addition, in a manuscript report, he described and drew in detail the objects he had found. He, too, collected objects and returned south with them (de Groot, 1983). The objects turned up in the Arkangel'sk Regional Museum. Unfortunately, other than the manuscript report (Kravchenko, 1983) and some short articles, no results of the work of Kravchenko have so far been published (Kravchenko, 1981; Kryuchkin, 1981, 1982).

We do not know who else has visited the site since then, but the objects in the Polar Museum in Tromsö in northern Norway indicate others have visited the site (Fig. 4).

\section{THE 1992 EXPEDITION}

In 1992 the Arctic and Antarctic Research Institute (AARI) in St. Petersburg, Russia and the Arctic Centre of the Univer-

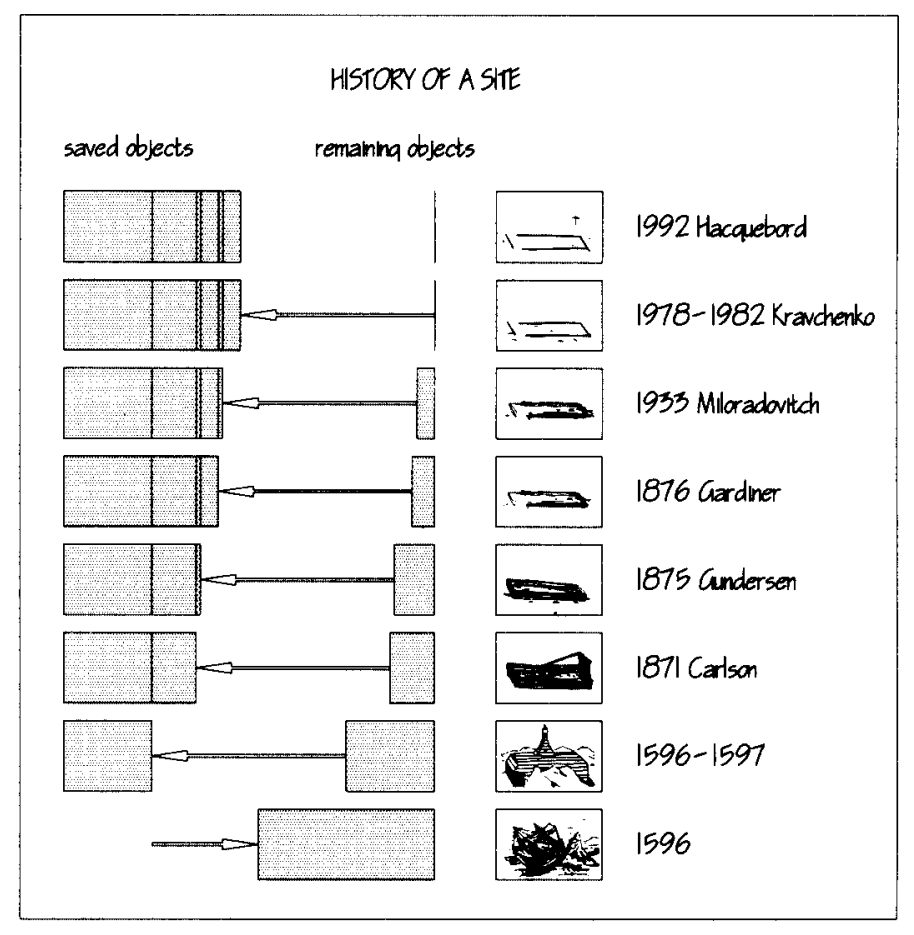

FIG. 4. History of the site (drawing by H.J. Waterbolk, photo by CFD-RUG).

sity of Groningen, The Netherlands gained permission from the Russian authorities to survey the wintering site of Willem Barentsz. Together the institutes composed an expedition team of six Dutchmen (three scientists, a journalist and a camera crew) and four Russians (two scientists, a cook and a doctor). On 20 August the expedition arrived at the peninsula of Mys Sporyy Navolok, near Ice Harbour or Bukhta Ledyanaya Gavan' on the northeastern side of Novaya Zemlya. The place was marked by a large wooden cross, and near the cross lay four huge, weathered, wind-bleached beams in the midst of a large amount of wooden remains. These beams formed a rectangle of $7.80 \mathrm{~m}$ by $5.50 \mathrm{~m}$ and, if Carlsen's measurements were correct, the beams had been moved since the discovery of the house in 1871. If this is true it might mean that any remaining objects are no longer in situ, which makes an excavation useless. Here and there the light grey, almost white colour of the beams had been changed to green as a result of the lichens growing on the weathered wood. The whole area was remarkable for its relatively dense vegetation. It was the only green spot on a seemingly endless peneplain, on which hardly anything grew, and which was grey and rustbrown. The place where Barentsz and his men spent the winter of 1596-97 was, therefore, not on the shore of a bay with hills as suggested by the illustrations in Gerrit de Veer's diary, but a flat, bare peninsula (Figs. 5 and 6). A huge wooden cross makes the spot easy to see from the Kara Sea. The cross was erected by Dmitriy Kravchenko in memory of Willem Barentsz (Kravchenko, 1981).

The western beam of the rectangle was a huge tree trunk which had been flattened on its upper surface by an adze. The tree trunk had probably originally come from Siberia, and it lay on large, flat stones. The southern beam lay on the western 


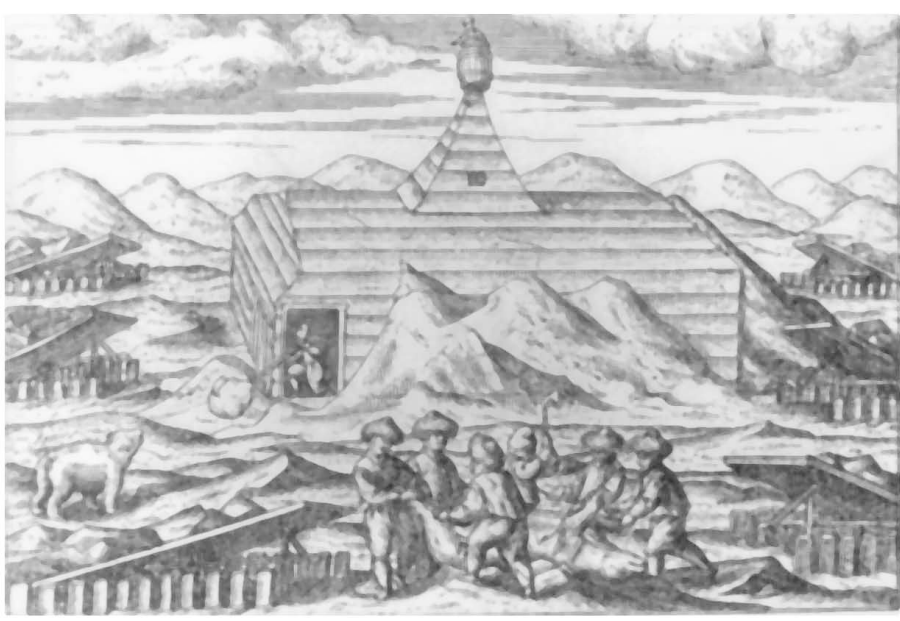

FIG. 5. Engraving of het Behouden Huys in its natural environment (l'Honoré Naber, 1917).

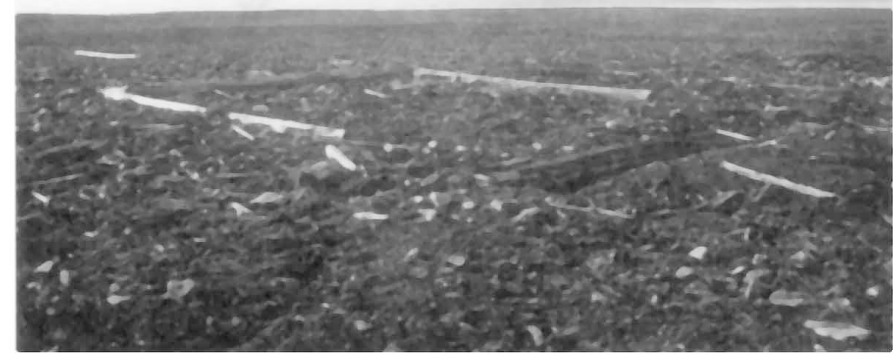

FIG. 6. The site of het Behouden Huys in 1992 (photo by L. Hacquebord).

beam, at right angles to it, and was flattened on one side. The other side was rounded, and except for three notches showed no signs of having been worked. It looked as if this beam was a piece of undressed timber from the ship, which had been reused in the construction of the house. Three nail holes were found in the flattened part, and some handmade nails lay nearby. Gerrit de Veer mentioned the use of such nails in his diary (de Veer, 1609:109).

The southern beam also partly rested on flat stones. Right at the other end the beam lay on a squared crossbeam. At this point the southern beam was carved out so that it fitted over the squared eastern beam (Fig. 7). These signs of work show that the lowest beams of the house at any rate were laid out as for a log cabin. The northern beam was also carved away on one side; the other side was very weathered and split. This beam, too, was lying on specially gathered flat stones, and about a third of the way along its supposed final length it had a notch into which a vertical beam, perhaps one of the doorposts of the inner door, was possibly secured. Thus it was established that in at least two places the base of the living quarters of the house was built in the log cabin manner, which is in accordance with what de Veer records in his diary (l'Honoré Naber, 1917: 76, 77, plate 13). In 1871, Carlsen, the discoverer of Barentsz's house, recorded a similar method of construction in his sketch (l'Honoré Naber, 1917:81). The

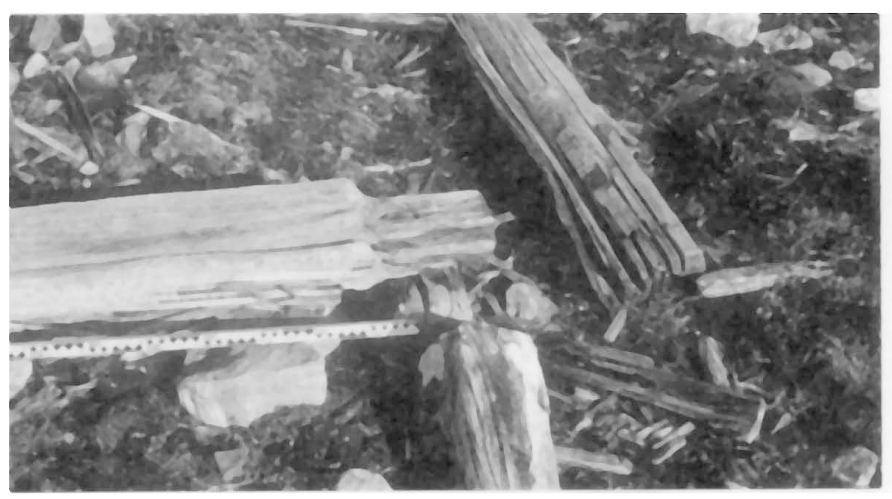

FIG. 7. The SE corner of het Behouden Huys with the southern beam carved out so that it fitted over the squared eastern beam (photo by L. Hacquebord).

frozen ground made it impossible to build the house on piles driven into the ground in the Dutch manner (de Veer, 1609:110).

Constructing the lower part of the living quarters of the house in the log cabin manner made the house much sturdier. The beams of the log cabin section were laid around the pairs of stakes to increase the sturdiness without having to dig the stakes in. The upper part of the house was boarded up with planks from Barentsz's ship. The log cabin section was four beams high, and the inner door probably sat on top of this in order not to affect the structure of the house and to preserve its sturdiness. Gerrit de Veer's diary has indications that a flight of steps was constructed on either side of the log cabin wall with the help of smaller beams (de Veer, 1609:158).

According to the illustrations in the diary of Gerrit de Veer (1609:115), the inner door must have been protected by a porch built onto the outside of the house. The location of this porch could still be seen in the field because of a raised area to the north of the log cabin section. The height of this raised area was the same as the floor level in the log cabin section of the house (Fig. 8). Thus the log cabin construction method was combined with the building on of a porch, which is a Dutch tradition (Zantkuijl, 1988). Barentsz had undoubtedly seen the log cabin construction method in Norway on one of his earlier trips to the north. This way of building was one of the first adaptations made by Europeans to the Arctic environment.

According to the diary, the beams of the preserved house were transported from a beach near a river approximately $6 \mathrm{~km}$ from the house on special sledges made for the purpose (de Veer, 1609:108). Exploration of the area showed that at about that distance away to the north there is indeed a beach with huge uprooted trees presumably from Siberia.

The remains of a fireplace could be seen in the middle of the rectangle of beams (Fig. 8). On the western side, a few meters away from the rectangle, lay a layer of rubbish; this included fragments of iron bands, originally from the barrels in which the beer from Danzig (Gdansk), called jopenbier, had been kept. Wood and tar remains were found at a spot on the southern side of the house. Here, too, were some logs and planks which must have originally been part of the house. A number of the logs would have been part of the supports of one side of the house, as shown in the illustrations in the diary. 


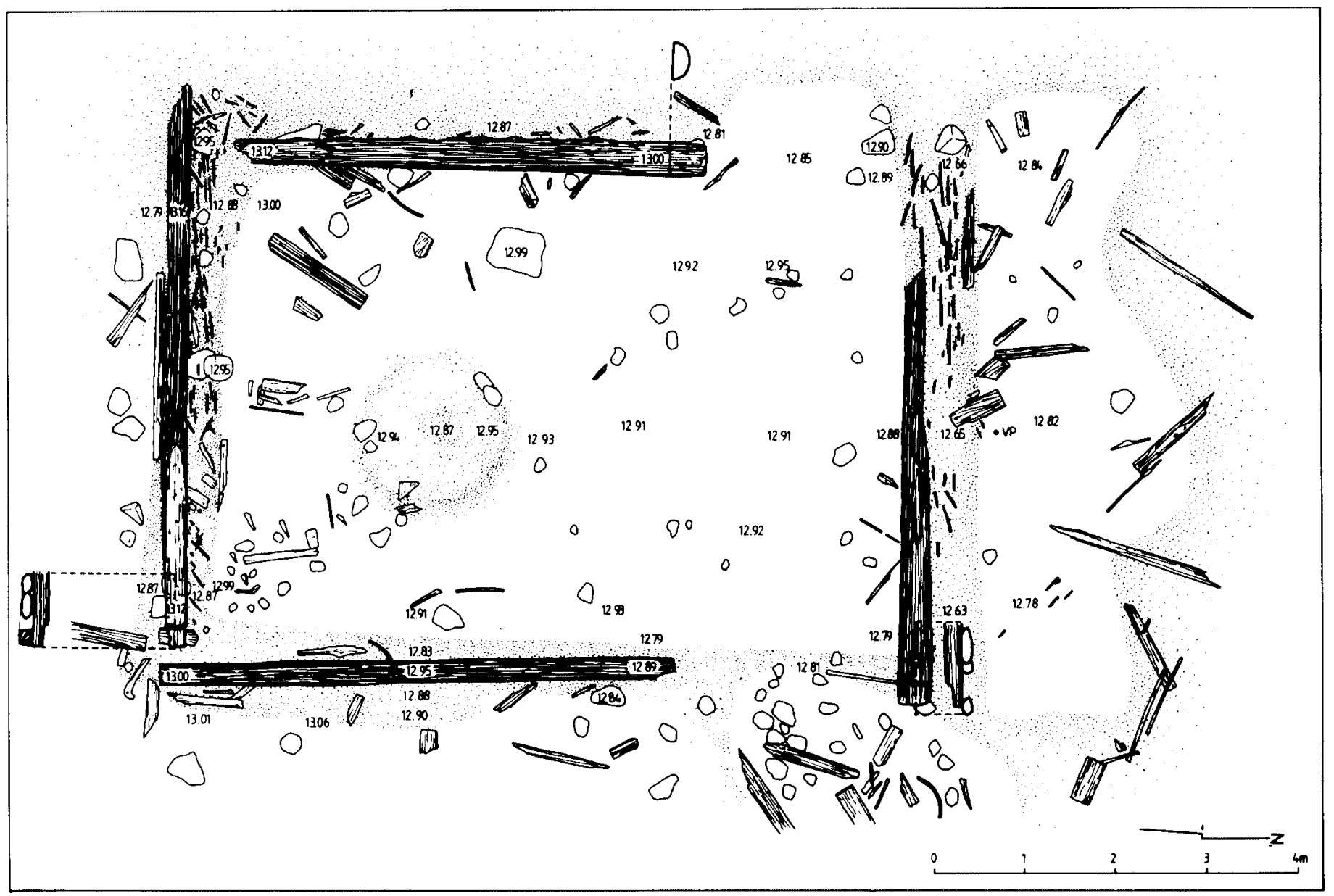

FIG. 8. Map of the site of het Behouden Huys on Novaya Zemlya in 1992, with the rectangle formed of beams, wooden objects, stones and micro-morphology. Inside the rectangle the remains of the fireplace are indicated, and on three points a cross-section is drawn. The numbers on the map give the heights above the average high seawater level (drawing by L. Hacquebord and H.J. Waterbolk, photo by CFD-RUG).

Their proximity and position show that these logs once stood on the southern side of the house, and this means that the illustrations in Gerrit de Veer's diary usually show a mirror image of the house.

\section{THE OBJECTS FROM NOVAYA ZEMLYA}

Most of the objects which have been found at the wintering site on Novaya Zemlya are part of the normal equipment of a sixteenth-century ship. The objects are well preserved, and their context has not been contaminated by objects from other, later periods.

The largest part of the collection is in the Rijksmuseum in Amsterdam. The Polar Museum in Tromsö in northern Norway has a large black felt hat and several smaller objects from Novaya Zemlya. The Arkangel'sk Regional Museum in Russia has around 1200 objects found by Kravchenko, including fragments of at least ten stoneware jugs, a Dutch duit [small copper coin], lots of bits of metal, iron tools, a lead mould, a lead polar bear, a few fragments of wood, and the lead compass card mentioned in de Veer's diary. The Arctic and Antarctic Museum in St. Petersburg also has a few objects from Novaya Zemlya. These include a stoneware jug with a medallion and a tin lid found at the site by Miloradovich, along with several nails, a wooden sole, a metal bottom, a key, a hinge, the base of a pottery pot with traces of some grease, and a piece of cork (Pineguine, 1933).

Despite the many objects already salvaged, it is still possible to find fragments of objects at the site. Thus in and around the rectangle of four beams, and scattered over several hundred square meters, were bits of wood of all sizes: fragments of pine planks which had all been used before, and oak staves from wine and beer barrels. Just like the beams, all of the wood fragments have been very bleached by the elements. Many of the wood fragments show signs of having been worked. These signs are often the result of the re-use of the material. As they lacked the right materials, the winterers often had to improvise. It appears from these objects that wood-carving was a favourite pastime (Fig. 9).

The large, attractive objects have disappeared. Most of them are in the various museums. What remains is the rubbish-the material which the visitors to het Behouden Huys did not think it worth their while to salvage. A lot of rubbish lies around het Behouden Huys itself. In addition to the fragments of wood, pieces of pottery, nails, copper trimmings, pieces of lead, fragments of shoes, and pieces of textile, some cattle bones were found. These bones are the 


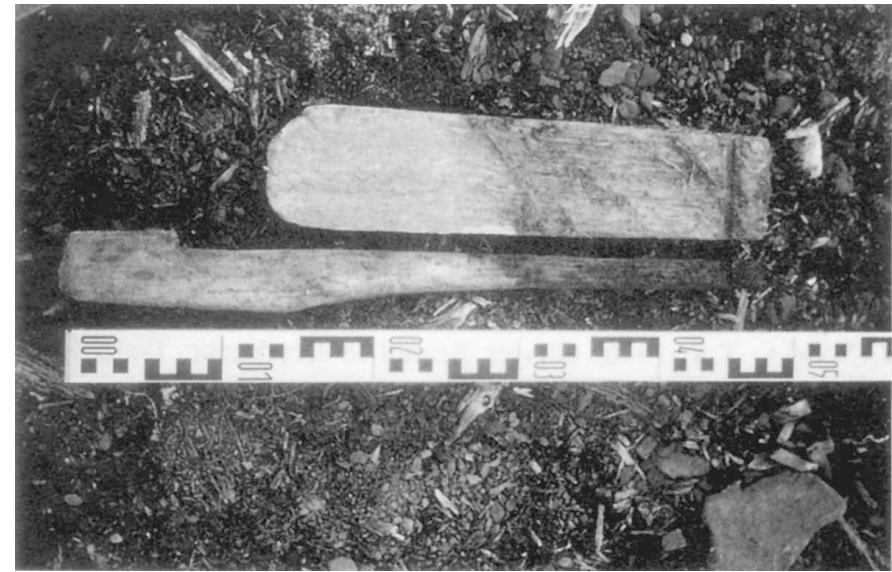

FIG. 9. Two stave fragments used for wood-carving (photo by L. Hacquebord).

remains of the salted beef that the winterers had brought with them in barrels from the Netherlands. The size of the bones and the butchering traces on them reveal how they had packaged the meat. The size of the bones showed that the meat had gone into the barrels in pieces of approximately the same size. The discovery of many ribs indicates that they gave preference to the chest pieces when salting and packaging the meat. In addition a shortage of meat is suggested, since almost all of the bones have been split to extract the marrow. Thanks to strict rationing, the winterers ate meat until well into the spring of 1597 . They cooked the last of the meat they had brought with them on 1 May 1597 (l'Honoré Naber, 1917:120; de Veer, 1609:173).

According to Gerrit de Veer's diary, in addition to salted beef they had brought smoked bacon and ham, smoked and dried fish, butter and cheese, ship's biscuit and hard bread, barley, peas and beans, groats and flour, oil and vinegar, mustard and salt, beer, wine, and brandy with them. None of this food, with the exception of the fish, grain and pulses, has left many traces at the site. The beer froze very rapidly, which caused the barrels to leak. When it was defrosted much of the precious fluid was lost as a result. In addition, the beer lost its strength and its taste after defrosting. As tea and coffee were not yet part of the provisions of a sixteenth-century ship, beer and wine were the most important drinks on board besides water. A shortage of beer was declared by 8 November and they began to melt snow. The rationing of bread was begun on the same day, and wine began to be rationed on 12 November. On 22 November, the cheese was divided up so that everyone could decide for himself how long to make his portion last. Despite rationing, the best provisions had already been finished by December. From then on the meals were very frugal.

Of all the foxes killed during the winter, only two lower jawbones remain. Fox meat was a welcome addition to the winterers' menu. The fresh meat helped to prevent scurvy, and the fact that they had access to it is certainly why they were able to survive. The foxes appeared once the polar bears had gone. They roamed about near the house throughout the winter. Traps were made to catch the animals, at first from a hoop and a rope, but very soon in the Norwegian manner with planks weighted by stones balanced on their edges. This latter method appears to have worked very well, as they caught a total of 26 foxes (de Veer, 1609:125). Only one bone from the eight bears killed by the castaways has been found. Before they arrived on Novaya Zemlya, they had discovered that bear meat was not very tasty and that consumption of the liver, which was tasty, made them very ill. On their arrival they found the bears a great nuisance. Later they mainly hunted them as a means of passing the time: they were not considered so valuable because the meat was not very tasty. The fat was used as fuel in the oil lamps and the skins were also usually kept (de Veer, 1609:155). In one case they also knocked out the teeth of a dead bear, but de Veer does not tell us what they did with them. The polar bears vanished once the sea had completely frozen and came back only in the spring.

\section{SUMMARY}

The field survey of the site, the exploration of the surroundings, and the historical investigation have resulted in some new facts. First, it appears that the house was built on a peninsula, and not on the shore of a bay as had been thought up to now. Next, the immediate surroundings of het Behouden Huys turned out to be flat, and not hilly as the illustrations in the diary suggested. If there was ever any question of hills, they must have been snowdrifts. The environment during Barentsz's stay must have been different from today's. The average temperature was a few degrees lower and, according to de Veer, the prevailing wind came from the northeast, whereas nowadays it is mostly southeasterly. When Barentsz sailed into the Kara Sea in August it was completely covered with ice, unlike today, and according to the diary, the land was completely frozen solid, also unlike today. There was no unfrozen upper layer, as there is at the present time.

The examination of the remains of the house has shown that the construction is different from the one Kravchenko supposed. Kravchenko's drawings show us four beams which are placed against the remains of three vertical stakes standing in the ground. They form a rectangle and reveal the size of the house. On the western side of the rectangle Kravchenko has drawn an extra vertical stake $1.25 \mathrm{~m}$ away from the nearest corner stake. In the middle of the house his map shows the remains of a fireplace, and in the northeastern corner he drew a rubbish heap with various objects in it. According to his drawing, to the west of the house and a little distant from it are a number of iron hoops which came from the barrels of jopenbier. To the southeast of the house he has indicated a fireplace with a lump of tar (Kravchenko, 1981).

During the 1992 visit, it became clear that the four beams near the cross do indeed form a rectangle, but nowhere could we find the remains of stakes or stake holes. There is no extra stake standing in the place Kravchenko indicates either. It is also very unlikely that they ever existed; because of the frozen ground, it was impossible to drive stakes into the ground. Everything points to the fact that the house was constructed in the log cabin manner, with beams which slotted into each 
other at the corners. This shows an adaptation to the frozen ground. On the basis of the micro-morphological and historical information it was possible to make a computer reconstruction of het Behouden Huys (Fig. 10). There were still traces of a fireplace to be seen in 1992, and the rubbish heap, although without the objects, still lay in the northeastern corner.

The comparison of the 1992 measurements with those taken by Carlsen made it clear that the beams have been moved and other objects are also presumably no longer in situ. The reduction in the amount of wood remains between 1980 and 1992 also shows that the decay of the location of the house where Willem Barentsz spent the winter is progressing very fast.
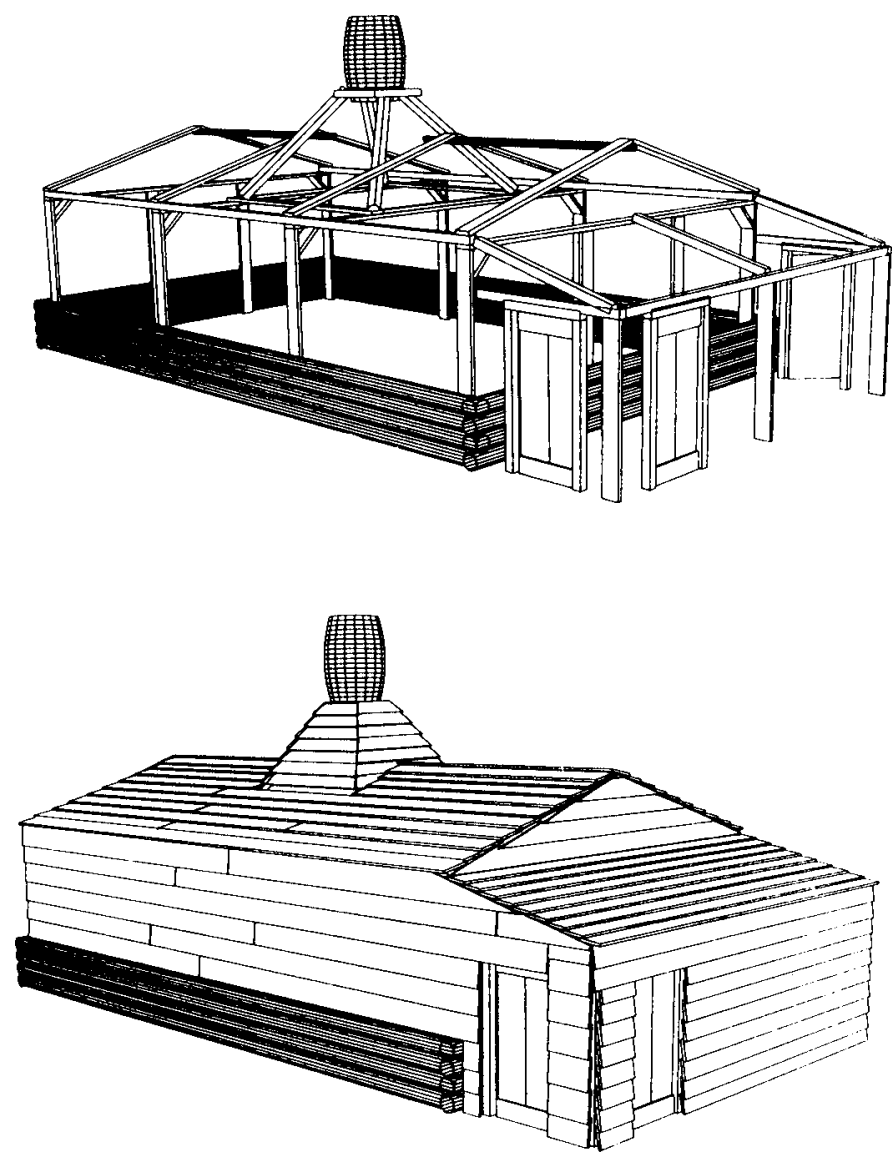

FIG. 10. Computer reconstruction of het Behouden Huys based on written information and field study (drawing by H.J. Waterbolk).

\section{REFERENCES}

ARMSTRONG, T. 1984. In search of a sea-route to Siberia, 1553 1619. Arctic 37(4):429-440.

BARON, S.H. 1985. Muscovy and the English quest for a northeastern passage to Cathay $(1553-1584)$. Acta Slavica Iaponica 3:1-17.

GROOT, R. de. 1983. Is vier maal scheepsrecht? Dmitri Krawtsjenko wederom op expeditie naar Nova Zembla. Tijdschrift van de Vereniging Nederland-USSR. January 1983:22-24.

HACQUEBORD, L. 1986. A survey of the early Dutch exploration and exploitation of the Atlantic Arctic. Circumpolar Journal 1 (2): $10-35$.

. 1991. Five early European winterings in the Atlantic Arctic (1596-1635): A comparison. Arctic 44(2):146-155.

HONORÉ NABER, S.P.l'. 1917. Reizen van Willem Barents, Jacob van Heemskerck, Jan Cornelisz Rijp en Anderen naar het Noorden 1594-1597. Publications of the Linschoten Society Vol. XIV and XV.'s Gravenhage: Martinus Nijhoff.

JANSMA, T.S. 1946. Olivier Brunel te Dordrecht: De Noordoostelijke doorvaart en het Westeuropeesch-Russisch contact in de zestiende eeuw. Tijdschrift voor Geschiedenis 59:337-362.

JONGE, J.K.J. de. 1872. Nova Zembla: De voorwerpen door de Nederlandsche Zeevaarders na hunne overwintering aldaar in 1597 achtergelaten en in 1871 door Kapitein Carlsen teruggevonden, beschreven en toegelicht. 's Gravenhage: Martinus Nijhoff.

- 1877. The Barents relics recovered in the summer of 1896 by Charles L.W. Gardiner. London: Trübner.

KERN, H. 1910. Itinerario: Voyage ofte Schipvaert van Jan Huygen van Linschoten naer Oost ofte Portugaels Indien, 1579-1592. 2 Volumes. Publication of the Linschoten Society, Vol. II. 's Gravenhage: Martinus Nijhoff.

KEUNING, J. 1946. Petrus Plancius, theoloog en geograaf $1522-$ 1622. Amsterdam: Van Kampen.

KRAVCHENKO, D. 1981. Mysterie van de 16de eeuw wordt ontraadseld! Tijdschrift van de Vereniging Nederland-USSR. June 1981:17-19.

- 1983. Otchet Arkticheskoy kompleksnoy poiskovistoricheskoy ekspeditsii (AKJE, 1979), Rukovoditel' D. Kravchenko (Report of the Arctic Complex Historical Survey Expedition [ACHE, 1979], Leader D. Kravchenko). Moskou.

KRYUCHKIN, V. 1981. Leto v ledyanoy gavani (A summer at Ice Harbour). Vokrug Sveta (Around the World), 1981 (8):14-19.

_ 1982. Po sledam ekspeditsii Barentsa (On the track of the Barentsz Expedition). Polyarnyy Krug (Polar Circle):238 - 247.

PINEGUINE, N. 1933. Nakhodka relikviy ekspeditsii Barentsa na Novoy Zemle (Relics of Barents' Expedition found on Novaya Zemlya). Bulleten' Arkticheskogo Instituta No. 12:423-424 and 460, Leningrad.

RESOLUTIONS OF THE STATES OF HOLLAND. 1789-1814. 289 volumes. Amsterdam.

TAYLOR, E.G.R. 1956. A letter dated 1577 from Mercator to John Dee. Imago Mundi XIII:56-69.

VEER, G. de. 1609. The True and perfect Description of three Voyages, so strange and woonderfull, that the like hath never been heard before. In: Phillip, W., ed., The Hakluyt Society Edition, 1876, London.

WAGHENAER, L.J. 1592. Thresoor der Zeevaert. Leiden: Frans van Raphelengen.

1596. Den Nieuwen Spieghel der Zeevaert. Amsterdam: Cornelis Claesz.

WALLIS, H. 1984. England's Search for the northern passages in the sixteenth and early seventeenth centuries. Arctic 37(4):453-472.

ZANTKUIJL, H.J. 1988. Reconstructie van de behuizing op Smeerenburg. In: L. Hacquebord, and Vroom, W.H., eds. Walvisvaart in de Gouden Eeuw. Opgravingen op Spitsbergen. Amsterdam: De Bataafsche Leeuw. 